\title{
PEMBUATAN MINYAK KEMIRI DAN PEMURNIANNYA DENGAN ARANG AKTIF DAN BENTONIT
}

\section{(Extraction and Purification of Candlenut Oil with Activated Charcoal and Clay-bentonite)}

\author{
Oleh / By :
}

Saptadi Darmawan ${ }^{1)}$

\begin{abstract}
Candle nut oil extraction can be applied in a simple and easy way. Preheating treatments on either the whole seed or the nut prior to pressing the nut in the oil extraction process, as well as the use of activated charcoal and bentonite in the purification process are believed to effect the quality of the oil. The aims of this investigation were 1) to know the effect of preheating on the yield and colour of the oil; and 2) to know the effect of type and concentration of the oil purifier (activated charcoal and bentonite) on physico-chemical properties of the oil. Preheating treatments tested were solar drying (3, 4, and 5 hours), heating $\left(7.5,12.5\right.$, and 17.5 minutes) and oven drying at $60^{\circ} \mathrm{C}(1,1.5$, and 2 hours $)$, tested the concentration of both activated charcoal and bentonite i.e. 2, 3 and $4 \%$. Oil extraction was conducted in bydraulic press at $60^{\circ} \mathrm{C}$. Result show that the best preheating treatment was heating in 1.5 hours, following by purification with 2\% activated charcoal gave optimum physico-chemical qualities to meet the Indonesian National Quality Standard's specific gravity, refraction index, iodine number and acid number.
\end{abstract}

Keywords : Candle nut oil, purification, activated charcoal, bentonite, physico-chemical qualities.

\begin{abstract}
ABSTRAK
Pembuatan minyak kemiri dapat dilakukan dengan cara sederhana dan mudah dilakukan oleh masyarakat. Perlakuan pemanasan pada biji kemiri dan daging kemiri sebelum proses pemecahan dan pengepresan serta penggunaan arang aktif dan bentonit pada tahap pemurnian minyak akan mempengaruhi kualitas minyak kemiri. Penelitian ini bertujuan untuk 1). mengetahui pengaruh pemanasan daging kemiri terhadap rendemen dan warna minyak yang dihasilkannya dan 2). mengetahui pengaruh jenis dan konsentrasi bahan pemucat (arang aktif dan bentonit) terhadap sifat fisiko-kimia minyak kemiri. Pemanasan pada biji kemiri berupa penjemuran $(3,4$ dan 5 jam), penyangraian $(7,5 ; 12,5$ dan 17,5 menit) dan pengovenan pada suhu $60^{\circ} \mathrm{C}(1 ; 1,5$ dan 2 jam) dimaksudkan untuk mendapatkan kondisi terbaik dalam pembuatan minyak kemiri dilihat dari rendemen dan warna minyaknya. Pembuatan minyak dilakukan dengan cara kempa hidraulik pada suhu $60^{\circ} \mathrm{C}$. Minyak kemiri yang dihasilkan dari kondisi terbaik (penyangraian selama 1,5 jam) kemudian dimurnikan menggunakan
\end{abstract}

\footnotetext{
${ }^{1)}$ Peneliti pada Balai Litbang Kehutanan Bali dan Nusa Tenggara, Kupang
} 
arang aktif dan bentonit pada konsentrasi $2 \%, 3 \%$ dan $4 \%$ serta diuji sifat fisiko-kimianya. Penggunaan arang aktif sebesar $2 \%$ menghasilkan sifat fisiko-kimia minyak kemiri yang optimum dan telah memenuhi Standar Nasional Indonesia untuk indeks bias, berat jenis, bilangan iod dan bilangan asam.

Kata kunci: Minyak kemiri, pemurnian, arang aktif, bentonit dan kualitas fisiko-kimia minyak kemiri.

\section{PENDAHULUAN}

Dalam dunia perdagangan, minyak kemiri banyak digunakan sebagai minyak pengering. Berdasarkan pengelompokannya, menurut Ketaren (1986) minyak kemiri termasuk dalam kelompok minyak lemak. Industri yang menggunakan minyak pengering diantaranya adalah industri cat, sabun dan kosmetik. Perdagangan kemiri di Indonesia umumnya masih dalam bentuk biji kemiri dan daging kemiri baik untuk kebutuhan domestik maupun ekspor.

Kualitas minyak kemiri akan dipengaruhi oleh proses pembuatannya yaitu pada tahap pemecahan biji kemiri, pembuatan minyak kemiri dan pemurnian minyak kemiri. Perlakuan yang biasa diterapkan pada tahap pemecahan biji kemiri adalah pemanasan biji kemiri sebelum dipecahkan yaitu perebusan, penyangraian dan penjemuran. Begitu juga pada tahap pembuatan minyaknya, cara atau tipe yang digunakan akan menentukan kualitas minyak yang dihasilkan. Tahapan terakhir adalah berupa pemurnian minyak kemiri, pada umumnya berupa pengurangan kadar air, penyaringan dan pemucatan.

Minyak kemiri diperoleh dari daging kemiri yang telah mengalami ekstraksi. Ekstraksi dapat dilakukan secara mekanis dan pelarutan (Ketaren, 1986). Cara mekanis lebih sederhana dan dapat dilakukan dengan pengempaan hidraulik atau pengempaan berulir. Pada pengempaan mekanis diperlukan perlakuan pendahuluan sebelum minyak/lemak dipisahkan untuk menghasilkan kualitas minyak lebih baik.

Tujuan penelitian ini adalah 1). untuk mengetahui pengaruh pemanasan pada daging kemiri terhadap rendemen dan warna minyak yang dihasilkannya dan 2). mengetahui pengaruh jenis dan konsentrasi bahan pemucat (arang aktif dan bentonit) terhadap sifat fisiko-kimia minyak kemiri. Dalam tulisan ini disajikan pembuatan dan pemurnian minyak kemiri.

\section{BAHAN DAN METODE}

\section{A. Bahan}

Bahan baku biji kemiri yang digunakan pada penelitian ini berasal dari Kab. Timor Tengah Utara, NTT. Bahan pemurni/pemucat yang digunakan adalah arang aktif tempurung kemiri dan bentonit. Sedangkan bahan kimia yang dipakai diantaranya kalium iodida, natrium thiosulfat, larutan kanji, asam klorida dan kalium hidroksida. Sedangkan peralatan yang digunakan diantaranya adalah alat pres minyak kemiri sistem kempa hidrolik, peralatan gelas kaca, oven, timbangan, magnetik heating stirer, buret, pipet, gelas ukur dan alat titrasi. 


\section{B. Metode}

Pada penelitian ini dilakukan dua kegiatan yaitu penelitian pendahuluan dan penelitian utama. Penelitian pendahuluan dilakukan guna menentukan kondisi pembuatan minyak kemiri yang optimal dilihat dari rendemen dan warna minyak yang dihasilkan. Penelitan utamanya adalah pemurnian minyak kemiri yang diperoleh pada kondisi optimum pembuatan minyak (hasil penelitian pendahuluan).

\section{Penelitian pendahuluan}

Perlakuan pendahuluan yang diterapkan adalah pemanasan terhadap daging kemiri sebelum dibuat minyaknya. Daging kemiri yang akan dipanaskan, dicincang terlebih dahulu guna mempercepat proses pengeringan dan meningkatkan rendemen minyaknya. Perlakuan pemanasan yang digunakan adalah penjemuran (selama 3, 4 dan 5 jam), penyangraian $(7,5$; 12,5 dan 17,5 menit) dan pengovenan pada suhu suhu $80^{\circ} \mathrm{C}(1 ; 1,5$ dan 2 jam). Daging kemiri yang telah dipanaskan dimasukkan dalam kain saring dan kemudian dipres dengan menggunakan alat pres sistem kempa hidraulik pada suhu $60^{\circ} \mathrm{C}$. Minyak yang dihasilkan ditentukan berat jenis, rendemen dan warnanya secara visual. Berdasarkan rendemen dan warna minyaknya maka ditentukan kondisi terbaik pembuatan minyak kemiri, di mana pada kondisi tersebut akan digunakan dalam pembuatan minyak kemiri selanjutnya.

\section{Penelitian utama}

Pemurnian minyak kemiri dilakukan menggunakan arang aktif dan bentonit dengan masing-masing 3 taraf yaitu 2; 3; 4 persen dan kontrol. Minyak kemiri dan bahan tersebut dipanaskan di atas magnetik heating striter pada suhu $100^{\circ} \mathrm{C}$ sambil terus diaduk. Selanjutnya disaring menggunakan kertas saring dibantu dengan alat vakum.

Minyak kemiri hasil pemurnian diuji sifat fisiko-kimianya berdasarkan prosedur standar (AOCS, 1951 dan Jacobs, 1958) yang meliputi kadar air, berat jenis, asam lemak bebas, indeks bias, bilangan iod, bilangan asam, bilangan penyabunan dan bilangan ester. Proses selengkapnya dapat dilihat pada bagan proses pemurnian minyak kemiri di bawah ini (Gambar 1).

Untuk mengetahui pengaruh dari faktor perlakuan yang diberikan serta interaksinya maka dilakukan uji statistik dengan menggunakan rancangan acak lengkap. Selanjutnya bila ada dari masing-masing faktor perlakuan atau interaksinya yang berpengaruh nyata maka dilakukan uji lanjutan Duncan (Duncan Multiple Range Test).

\section{HASIL DAN PEMBAHASAN}

\section{A. Penelitian Pendahuluan Pembuatan Minyak Kemiri}

Penelitian pendahuluan ini dimaksudkan untuk menentukan perlakuan pemanasan terbaik pada daging kemiri sebelum dibuat minyaknya yang dinilai dari rendemen dan warna minyaknya. Pemanasan daging kemiri dimaksudkan untuk mengkoagulasikan protein dalam biji sehingga diharapkan diperoleh rendemen minyak yang lebih besar, di samping itu juga untuk menurunkan kadar air sehingga mengurangi terjadinya hidrolisis atau kerusakan minyak (Ward, 1982). 


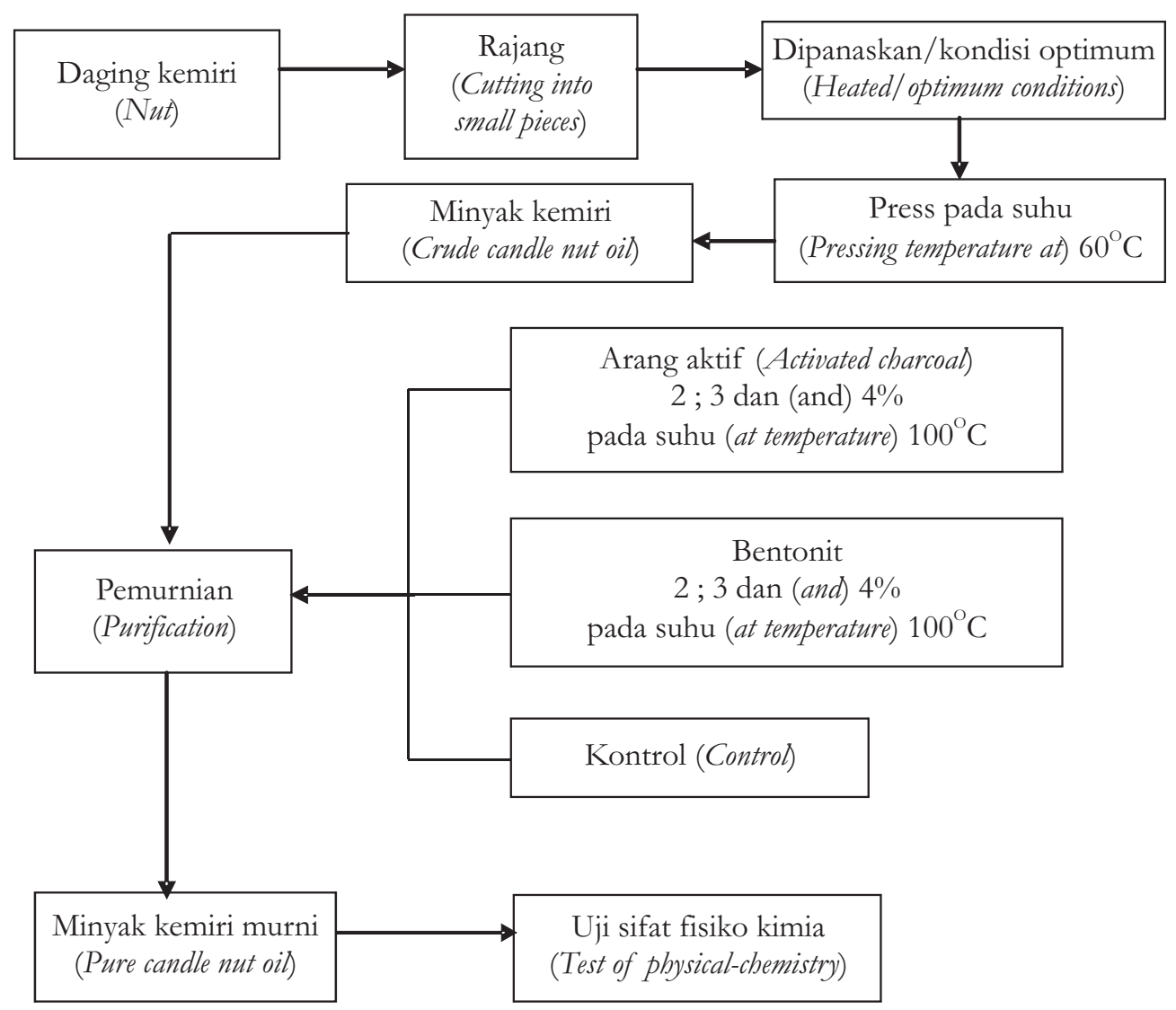

\section{Gambar 1. Bagan proses pemurnian minyak kemiri Figure 1. Scheme of candle nut purification process}

Rendemen minyak kemiri yang dihasilkan berkisar antara 33,12\%-39,14\%. Pemanasan dengan cara pengovenan selama 90 menit pada suhu $90^{\circ} \mathrm{C}$ menghasilkan rendemen tertinggi dan warna minyak yang baik. Berdasarkan analisa statistik (Tabel 3) juga nampak bahwa rendemen pada kondisi tersebut berbeda sangat nyata dengan perlakuan lainnya. Sedangkan rendemen terendah diperoleh dari hasil penyangraian selama 17,5 menit. Masing-masing jenis pemanasan yaitu pengovenan, penyangraian dan perebusan berdasarkan analisa statistik pada Tabel 2 memberikan pengaruh yang berbeda terhadap rendemen minyak yang dihasilkan. Rendemen rata-rata tertinggi dihasilkan dari perlakuan pengovenan kemudian diikuti penyangraian dan penjemuran yaitu masing-masing sebesar 36,40\%, 34,94\% dan $33,67 \%$. Pemanasan dengan cara di oven dapat memberikan pemanasan yang konstan dan merata pada setiap permukaan sehingga pada saat pengepresan minyak yang dikeluarkan lebih banyak. Menurut Ward (1982) salah satu fungsi pemanasan adalah untuk meng koagulasi protein sehingga mempermudah minyak yang dikeluarkan dari bahan tersebut. 
Tabel 1. Sifat minyak kemiri pada penelitian pendahuluan Table 1. Properties of candle nut oil at preliminary research

\begin{tabular}{|l|c|c|c|c|}
\hline \multicolumn{2}{|c|}{ Pemanasan (Heating) } & \multicolumn{3}{c|}{ Sifat minyak kemiri (Properties of candle nut oil) } \\
\hline $\begin{array}{c}\text { Jenis } \\
\text { (Type) }\end{array}$ & $\begin{array}{c}\text { Waktu (Time) / } \\
\text { menit (minute) }\end{array}$ & $\begin{array}{c}\text { Berat jenis } \\
\text { (Specific gravity) }\end{array}$ & $\begin{array}{c}\text { Rendemen } \\
\text { (Yield), \% }\end{array}$ & $\begin{array}{c}\text { Warna } \\
\left.(\text { Colour })^{\text {) }}\right)\end{array}$ \\
\hline Oven & 60,0 & 0,9259 & 35,00 & $\mathrm{a}$ \\
& 90,0 & 0,9230 & 39,14 & $\mathrm{a}$ \\
& 120,0 & 0,9254 & 35,07 & $\mathrm{~b}$ \\
\hline Sangrai & 7,5 & 0,9240 & 36,13 & $\mathrm{a}$ \\
(Heating up) & 12,5 & 0,9237 & 35,56 & $\mathrm{~b}$ \\
& 17,5 & 0,9250 & 33,12 & $\mathrm{c}$ \\
\hline Jemur & 180,0 & 0,9248 & 33,57 & $\mathrm{a}$ \\
(Solar drying) & 240,0 & 0,9247 & 33,84 & $\mathrm{a}$ \\
& 300,0 & 0,9252 & 33,60 & $\mathrm{a}$ \\
\hline Kontrol (Control) & & 0,9255 & 33,23 & \\
\hline
\end{tabular}

Keterangan (Remarks) : a > b >c, warna lebih bening/terang (colour more light than)

Pada proses penyangraian nampaknya kontak langsung antara bahan yaitu daging kemiri dengan wajan saat pemanasan pada suhu tinggi telah menyebabkan terjadinya pengerakan dan warna kemiri menjadi lebih gelap dibanding sebelumnya. Pengerakan sebagian besar terjadi pada kemiri yang berukuran kecil di mana semakin lama pemanasan menyebabkan kerak yang dihasilkan juga semakin besar. Sebelum proses pengepresan untuk dibuat minyaknya kerak-kerak tersebut dipisahkan/dibuang sehingga secara langsung akan mengurangi rendemen minyak yang nantinya akan dihasilkan. Pengaruh lainnya adalah warna minyak yang dihasilkan menjadi lebih gelap dibandingkan perlakuan pengovenan dan penjemuran. Menurut Ketaren (1986) zat warna di dalam minyak terdiri dari dua golongan yaitu zat warna alamiah dan hasil degradasi zat warna tersebut. Warna gelap pada minyak juga dapat disebabkan oleh proses oksidasi pada sebagian minyak karena pemanasan yang tinggi.

Penjemuran daging kemiri belum mampu menghasilkan rendemen yang lebih baik dibanding perlakuan lainnya namun rendemennya lebih tinggi bila dibandingkan dengan kontrol. Keunggulan dari perlakuan ini adalah warna minyak yang dihasilkan lebih baik dibandingkan hasil penyangraian. Berdasarkan rendemen dan warna minyak tersebut maka kondisi terbaik pembuatan minyak kemiri adalah dengan pengovenan selama 90 menit pada suhu $80^{\circ} \mathrm{C}$.

\section{B. Pemurnian Minyak Kemiri}

Berdasarkan penelitian pendahuluan yang dilakukan maka kondisi optimum pembuatan minyak kemiri adalah melalui pemanasan daging kemiri menggunakan oven selama 1,5 jam pada suhu $80^{\circ} \mathrm{C}$. Pada kondisi tersebut maka dibuat minyak kemiri yang kemudian digunakan dalam proses pemurnian minyak dengan menggunakan bentonit dan arang aktif tempurung kemiri dengan persentase 2, 3 dan 4 persen. 
Tabel 2. Analisa sidik ragam rendemen minyak kemiri pada penelitian pendahuluan Table 2. Analysis of variance on candle nut oil yield at preliminary research

\begin{tabular}{|l|c|c|c|c|}
\hline \multicolumn{1}{|c|}{$\begin{array}{c}\text { Sumber } \\
\text { (Source) }\end{array}$} & $\begin{array}{c}\mathrm{Db} \\
(\mathrm{Df})\end{array}$ & $\begin{array}{c}\text { Jumlah kuadrat } \\
(\text { Sum of square) }\end{array}$ & $\begin{array}{c}\text { Kuadrat tengah } \\
\text { (Mean square) }\end{array}$ & $\begin{array}{c}\text { Peluang } \\
\text { (Probability) }\end{array}$ \\
\hline Pemanasan (Heating) / A & 2 & 22,4533 & 11,2267 & $0,0003^{* *}$ \\
\hline Waktu (Time) / Q & 2 & 15,2836 & 7,6418 & $0,0011^{* *}$ \\
\hline Interaksi (Interaction) /A*Q & 4 & 17,5027 & 4,3757 & $0,0030^{* *}$ \\
\hline Galat (Error) & 9 & 4,2670 & 0,4741 & \\
\hline Sisa (Residual) & 17 & 59,5066 & & \\
\hline
\end{tabular}

Keterangan (Remarks) : ** = Berpengaruh sangat nyata (Highly significance)

Tabel 3. Uji beda nyata Duncan randemen minyak pada penelitian pendahuluan Table 3. Duncan multiple range test of candle nut oil yield on preliminary research

\begin{tabular}{|c|c|c|c|c|}
\hline \multirow[b]{2}{*}{ No. } & \multicolumn{2}{|c|}{ Pemanasan (Heating) } & \multirow{2}{*}{$\begin{array}{l}\text { Nilai rata-rata } \\
\text { (Average value) }\end{array}$} & \multirow{2}{*}{$\begin{array}{c}\text { Uji Beda') } \\
\text { (Different test) }\end{array}$} \\
\hline & $\begin{array}{l}\text { Jenis } \\
(\text { Type })\end{array}$ & $\begin{array}{l}\text { Waktu (Time), } \\
\text { menit (minute) }\end{array}$ & & \\
\hline 1 & Oven & 90,0 & 39,14 & $\mathrm{~A}$ \\
\hline 2 & Sangrai (Heating up) & 7,5 & 36,13 & B \\
\hline 3 & Sangrai (Heating up) & 12,5 & 35,56 & $\mathrm{~B}$ \\
\hline 4 & Oven & 120,0 & 35,07 & $\mathrm{BC}$ \\
\hline 5 & Oven & 60,0 & 35,00 & $\mathrm{BC}$ \\
\hline 6 & Jemur (Solar drying) & 180,0 & 33,84 & $\mathrm{CD}$ \\
\hline 7 & Jemur (Solar drying) & 240,0 & 33,60 & $\mathrm{CD}$ \\
\hline 8 & Jemur (Solar drying) & 300,0 & 33,57 & $\mathrm{CD}$ \\
\hline 9 & Sangrai (Heating up) & 17,5 & 33,12 & $\mathrm{D}$ \\
\hline
\end{tabular}

Keterangan (Remarks) : 1) Huruf yang sama tidak berbeda nyata (The same letter are not significantly different)

Kadar air yang diperoleh pada penelitian ini cukup bervariasi dengan kadar air terendah dihasilkan dari pemurnian minyak menggunakan arang aktif $4 \%$ yaitu sebesar $0,47 \%$ dan tertinggi dari penggunaan bentonit sebesar 4\% dengan kadar air 0,99\%. Kadar air hasil perlakuan dan kontrol pada penelitian ini belum memenuhi Standar Nasional Indonesia (SNI). Persyaratan kadar air yang ditetapkan SNI maksimal adalah 0,15\%.

Pemberian arang aktif dan bentonit pada proses pemurnian minyak kemiri ini memberikan reaksi yang berbeda. Kadar air minyak cenderung menurun dengan meningkatnya konsentrasi arang aktif yang digunakan dan sebaliknya, kadar air cenderung meningkat dengan bertambahnya konsentrasi bentonit. Hal ini menunjukkan bahwa arang aktif mampu mengikat kandungan air di dalam minyak. Sebaliknya dengan bentonit, 
pemakaian sebesar 2\% telah berhasil mendapatkan kadar air terendah dan cenderung meningkat dengan bertambahnya bentonit. Berdasarkan analisa sidik ragam sebagaimana terdapat pada Tabel 5, penggunaan jenis adsorben dan konsentrasinya, tidak berpengaruh nyata terhadap kadar air yang dihasilkan.

\section{Tabel 4. Sifat minyak kemiri}

\section{Table 4. Properties of candle nut oil}

\begin{tabular}{|c|c|c|c|c|c|c|c|c|c|}
\hline \multirow[b]{2}{*}{$\begin{array}{l}\text { Adsorben } \\
\text { (Adsorbent) }\end{array}$} & \multirow{2}{*}{$\begin{array}{c}\text { Konsen- } \\
\text { trasi } \\
\text { (Concen- } \\
\text { tration), } \\
\%\end{array}$} & \multirow{2}{*}{\begin{tabular}{|} 
Kadar \\
air \\
(Moisture \\
content $)$ \\
$\%$
\end{tabular}} & \multirow{2}{*}{$\begin{array}{c}\text { Berat } \\
\text { jenis (Specific } \\
\text { gravity) }\end{array}$} & \multirow[b]{2}{*}{$\begin{array}{c}\text { Indeks Bias } \\
\text { (Refraction index) }\end{array}$} & \multirow{2}{*}{$\begin{array}{l}\text { Asam } \\
\text { lemak } \\
\text { bebas } \\
\text { (Free fatty } \\
\text { acid) }\end{array}$} & \multicolumn{4}{|c|}{ Bilangan (Number of) } \\
\hline & & & & & & $\begin{array}{c}\text { Iod } \\
\text { (Iodine) }\end{array}$ & $\begin{array}{l}\text { Asam } \\
\text { (Acid) }\end{array}$ & $\begin{array}{l}\text { Penya- } \\
\text { bunan } \\
\text { (Saponi- } \\
\text { fication }\end{array}$ & Ester \\
\hline \multirow{3}{*}{$\begin{array}{l}\text { Arang } \\
\text { aktif } \\
\text { (Activated } \\
\text { charcoal) }\end{array}$} & 2 & 0,911 & 0,9245 & \multirow{2}{*}{$\begin{array}{l}1,4752 \\
1,4755\end{array}$} & 1,5950 & 138,600 & 4,5800 & 169,9500 & 165,370 \\
\hline & 3 & 0,629 & 0,9230 & & 1,6200 & 126,600 & 4,5350 & 171,4750 & 166,940 \\
\hline & 4 & 0,474 & 0,9228 & 1,4755 & 1,6150 & 125,900 & 4,7950 & 175,8600 & 171,065 \\
\hline \multirow[t]{3}{*}{ Bentonit } & 2 & 0,589 & 0,9232 & \multirow{3}{*}{$\begin{array}{l}1,4754 \\
1,4754 \\
1,4754\end{array}$} & 1,7350 & 123,400 & 4,5750 & 169,9200 & 165,345 \\
\hline & 3 & 0,809 & 0,9228 & & 1,6650 & 129,500 & 4,6500 & 176,9400 & 172,290 \\
\hline & 4 & 0,992 & 0,9229 & & 1,6800 & 125,400 & 4,4800 & 178,6400 & 174,160 \\
\hline $\begin{array}{l}\text { Kontrol } \\
\text { (Contro) }\end{array}$ & & 0,864 & 0,9224 & 1,4753 & 1,7000 & 130,200 & 4,8700 & 179,9400 & 175,070 \\
\hline $\left.\mathrm{SNI}^{*}\right)$ & & $<0,1500$ & $0,9240-0,9290$ & $1,4730-1,4790$ & $0,1-1,5$ & $136-167$ & $\operatorname{Max} 5^{* *}$ & $184-202$ & \\
\hline
\end{tabular}

Keterangan (Remarks) : * SNI 01-4462-1998; ** SNI 01-1684-1998

Berat jenis minyak kemiri tertinggi diperoleh dari hasil penggunaan adsorben arang aktif $2 \%$ yaitu sebesar 0,9245 . Besarnya nilai berat jenis tersebut telah memenuhi berat jenis yang dipersyaratkan SNI yaitu 0,9240 0,9290. Sedangkan berat jenis terendah dihasilkan dari kontrol yaitu sebesar 0,9224. Selanjutnya hasil analisa sidik ragam menunjukkan bahwa terdapat perbedaan berat jenis yang signifikan antara penggunaan arang aktif dan kontrol. Penetapan berat jenis berfungsi untuk menginformasikan berat suatu bahan, dalam hal ini minyak kemiri dan untuk perhitungan rendemen. Ada sebagian pendapat yang mengemukakan bahwa berat jenis juga berperan untuk melihat kemurnian minyak kemiri. Berdasarkan Tabel 4 di atas nampak bahwa dengan penambahan adsorben baik arang aktif maupun bentonit telah berhasil meningkatkan berat jenis dibandingkan dengan kontrol. Peristiwa ini kemungkinan disebabkan oleh terserapnya fraksi ringan pada minyak oleh adsorben yang digunakan (Yusnita et al., 1990). Selanjutnya dengan semakin besarnya penambahan konsentrasi adsorben justru menurunkan berat jenisnya walaupun pengaruhnya tidak nyata. Semakin besar konsentrasi adsorben kemungkinan menyebabkan adanya reaksi antara adsorben dengan minyak yang menyebabkan terserapnya asam lemak bebas (ALB) pada minyak sehingga menurunkan berat jenisnya.

Indeks bias dari semua perlakuan yang diberikan telah memenuhi standar SNI yaitu berada di antara 1,4730 - 1,4790. Indeks bias yang dihasilkan tidak jauh berbeda yaitu berkisar antara 1,4752 sampai dengan 1,4755. Berdasarkan analisa sidik ragam juga memperlihatkan bahwa indeks bias yang dihasilkan tidak berpengaruh nyata dari perlakuan yang diberikan. Penentuan indeks bias dimaksudkan untuk mengetahui keragaman indeks bias minyak kemiri. 
Kadar asam lemak bebas menunjukkan kualitas minyak yang dihasilkan. Minyak dengan ALB tinggi tidak akan tahan disimpan dalam waktu lama atau cepat rusak. Kadar ALB pada penelitian ini belum memenuhi standar SNI, yaitu masih di atas 1,5. Namun telah memenuhi spesifikasi minyak biji rami yang dijadikan standar dalam pembuatan cat dan vernis yaitu maksimum 2\% (Yusnita et al., 1999). Secara umum pemberian adsorben telah berhasil menurunkan kadar asam lemak dalam minyak dibandingkan dengan kontrol. Asam lemak bebas tertinggi dihasilkan dari penggunaan bentonit $\%(1,7350)$ dan kontrol $(1,7000)$. Penggunan arang aktif sebesar 2\% telah mampu menurunkan kadar ALB menjadi 1,5950 namun belum mampu memenuhi standar SNI. Berdasarkan analisa sidik ragam, pemberian perlakuan ternyata belum mampu menghasilkan kadar ALB secara nyata.

Bilangan iod merupakan parameter penting bagi penentuan kualitas minyak mengering (minyak kemiri) yang menunjukkan ukuran ketidakjenuhan minyak mengering. Pada minyak mengering diharapkan mempunyai bilangan iod yang tinggi. Menurut Mills dalam Yusnita (1999), penggolongan minyak mengering adalah di atas 130. Bilangan iod dari hasil penggunaan arang aktif $2 \%$ adalah yang tertinggi yaitu sebesar 138,600 diikuti kontrol sebesar 130,200. Bilangan iod terendah dihasilkan dari pemberian bentonit 4\% yaitu 125,400. Penambahan arang aktif dan bentonit pada minyak kemiri ternyata cenderung menurunkan bilangan iod (Tabel 4) tetapi berdasarkan analisa statistik, pengaruhnya tidak nyata (Tabel 5). Hal tersebut dimungkinkan karena adanya reaksi antara adsorben dengan minyak yang menyebabkan terputusnya ikatan rangkap pada minyak sehingga menurunkan bilangan iodnya.

Bilangan asam yang diperoleh dari kontrol menghasilkan nilai tertinggi yaitu sebesar 4,8700. Pemberian adsorben arang aktif dan bentonit telah berhasil menurunkan kandungan bilangan asam dalam minyak menjadi antara 4,4800 - 4,7950 namun pengaruhnya tidak nyata. Keseluruhan bilangan asam pada penelitian ini telah memenuhi Standar Nasional Indonesia (SNI 01-1684-1998).

Paramaeter bilangan penyabunan digunakan untuk menentukan jumlah asam lemak baik dalam keadaan bebas maupun terikat di dalam molekul trigliserida atau menghitung jumlah asam lemak total di dalam molekul trigliserida. Besarnya bilangan penyabunan berhubungan terbalik dengan berat molekul (berat jenis) di mana semakin tinggi berat molekul maka bilangan penyabunan akan semakin rendah dan sebaliknya (Sudarmadji, 1989 dan Plofesi, 1997). Bilangan penyabunan tertinggi dihasilkan dari kontrol yaitu sebesar 179,9400. Secara umum pemberian adsorben arang aktif dan bentonit pada minyak kemiri ternyata telah berhasil menurunkan bilangan penyabunan dibandingkan dengan kontrol. Bilangan penyabunan terendah dihasilkan dari penggunaan bentonit $2 \%$ dan arang aktif $2 \%$ yaitu 169,92 dan 169,95. Selanjutnya data bilangan ester juga menunjukkan kecenderungan yang sama dengan bilangan penyabunan. Nilai bilangan ester terendah $(165,345$ dan 165,370) dihasilkan pada penggunaan bentonit dan arang aktif $2 \%$.

Berdasarkan analisa sidik ragam uji beda Duncan pada Tabel 5 dan 6, menunjukkan bahwa masing-masing jenis dan persentase adsorben memberikan pengaruh nyata terhadap bilangan penyabunan dan bilangan ester. Sedangkan pada kombinasi perlakuan, pemberian arang aktif sebesar $3 \%$ dan $2 \%$ serta bentonit $2 \%$ pengaruhnya tidak berbeda. 
Tabel 5. Ringkasan sidik ragam sifat minyak kemiri

Table 5. Summarized analysis of variance on properties of candle nut oil

\begin{tabular}{|c|c|c|c|c|}
\hline No. & $\begin{array}{c}\text { Sifat } \\
\text { (Properties) }\end{array}$ & $\begin{array}{l}\text { Perlakuan } \\
\text { (Treatment) }\end{array}$ & $\begin{array}{l}\text { Kuadrat tengah } \\
\text { (Mean square) }\end{array}$ & $\begin{array}{l}\text { F hitumg } \\
\text { (F calculated })\end{array}$ \\
\hline 1 & $\begin{array}{l}\text { Kadar air } \\
\text { (Moisture content), \% }\end{array}$ & $\begin{array}{c}\mathrm{A} \\
\mathrm{B} \\
\mathrm{AB}\end{array}$ & $\begin{array}{l}0,0004745 \\
0,0000096 \\
0,0017855\end{array}$ & $\begin{array}{l}0,48 \\
0,01 \\
1,80\end{array}$ \\
\hline 2 & $\begin{array}{l}\text { Bobot jenis } \\
\text { (Specific gravity) }\end{array}$ & $\begin{array}{c}\mathrm{A} \\
\mathrm{B} \\
\mathrm{AB}\end{array}$ & $\begin{array}{l}0,0000007 \\
0,0000013 \\
0,0000006\end{array}$ & $\begin{array}{l}1,94 \\
3,86 \\
1,83\end{array}$ \\
\hline 3 & $\begin{array}{l}\text { Indeks bias } \\
\text { (Refractive index) }\end{array}$ & $\begin{array}{c}\mathrm{A} \\
\mathrm{B} \\
\mathrm{AB}\end{array}$ & $\begin{array}{l}0,00000000 \\
0,00000003 \\
0,00000003\end{array}$ & $\begin{array}{l}0,00 \\
1,20 \\
1,20\end{array}$ \\
\hline 4 & $\begin{array}{l}\text { Kadar asam lemak } \\
\text { bebas } \\
\text { (Free fatty acid content) }\end{array}$ & $\begin{array}{c}\mathrm{A} \\
\mathrm{B} \\
\mathrm{AB}\end{array}$ & $\begin{array}{l}0,0208300 \\
0,0005583 \\
0,0025083\end{array}$ & $\begin{array}{l}3,51 \\
0,09 \\
0,42\end{array}$ \\
\hline 5 & $\begin{array}{l}\text { Bilangan iod } \\
\text { (Iod number) }\end{array}$ & $\begin{array}{c}\mathrm{A} \\
\mathrm{B} \\
\mathrm{AB}\end{array}$ & $\begin{array}{l}54,6133333 \\
28,7233333 \\
92,5433333\end{array}$ & $\begin{array}{l}1,07 \\
0,56 \\
1,81\end{array}$ \\
\hline 6 & $\begin{array}{l}\text { Bilangan asam } \\
\text { (Acid number) }\end{array}$ & $\begin{array}{c}\mathrm{A} \\
\mathrm{B} \\
\mathrm{AB}\end{array}$ & $\begin{array}{l}0,0140083 \\
0,0039000 \\
0,0492333\end{array}$ & $\begin{array}{l}1,40 \\
0,39 \\
4,93\end{array}$ \\
\hline 7 & $\begin{array}{l}\text { Bilangan penyabunan } \\
\text { (Saponification number) }\end{array}$ & $\begin{array}{c}\mathrm{A} \\
\mathrm{B} \\
\mathrm{AB}\end{array}$ & $\begin{array}{r}22,4954083 \\
54,0135250 \\
7,5500583\end{array}$ & $\begin{array}{c}21,61 * * \\
51,89 * * \\
7,25 *\end{array}$ \\
\hline 8 & $\begin{array}{l}\text { Bilangan ester } \\
\text { (Ester number) }\end{array}$ & $\begin{array}{c}\mathrm{A} \\
\mathrm{B} \\
\mathrm{AB}\end{array}$ & $\begin{array}{l}23,6320000 \\
53,1640000 \\
7,28500000\end{array}$ & $\begin{array}{c}25,73 * * \\
57,89 * * \\
7,93 *\end{array}$ \\
\hline
\end{tabular}

Keterangan (Remarks) : $\mathrm{A}=$ Jenis adsorben (Type of adsorbent); $\mathrm{B}=$ Konsentrasi (Concentration of adsorbent); $\mathrm{AB}=$ Interaksi (Interaction); * = Pengaruh nyata (Significant); ** = Pengaruh sangat nyata (Highly significant)

\section{KESIMPULAN DAN SARAN}

Berdasarkan rendemen dan warna minyak kemiri, kondisi terbaik pembuatan minyak kemiri adalah dengan cara pemanasan daging kemiri menggunakan oven pada suhu $80^{\circ} \mathrm{C}$ selama 1,5 jam yang kemudian dikempa pada suhu $60^{\circ} \mathrm{C}$ yaitu sebesar $39,14 \%$.

Pemakaian arang aktif sebesar $2 \%$ menghasilkan sifat fisiko-kimia minyak kemiri yang optimum, yaitu untuk indeks bias, berat jenis, bilangan iod dan bilangan asam dan telah memenuhi Standar Nasional Indonesia. Pemurnian minyak kemiri dengan menggunakan arang aktif dan bentonit sebesar 2, 3 dan 4 persen dengan kondisi pemurnian yang digunakan, belum mampu menghasilkan kualitas minyak yang diharapkan. 
Tabel 6. Uji beda nyata Duncan bilangan penyabunan Table 6. Duncan multiple range test of saponification number

\begin{tabular}{|c|c|c|c|c|}
\hline \multirow[b]{2}{*}{$\begin{array}{l}\text { Perlakuan } \\
\text { (Treatment) }\end{array}$} & \multicolumn{2}{|c|}{$\begin{array}{l}\text { Bilangan penyabunan } \\
\text { (Saponification number) }\end{array}$} & \multicolumn{2}{|c|}{$\begin{array}{c}\text { Bilangan ester } \\
\text { (Ester number) }\end{array}$} \\
\hline & $\begin{array}{l}\text { Nilai rata- } \\
\text { rata } \\
\text { (Average } \\
\text { value })\end{array}$ & $\begin{array}{l}\text { Uji beda } 1) \\
\text { (Different } \\
\text { test) }\end{array}$ & $\begin{array}{l}\text { Nilai rata- } \\
\text { rata } \\
\text { (Average } \\
\text { value) }\end{array}$ & $\begin{array}{l}\text { Uji beda } 1) \\
\text { (Different } \\
\text { test) }\end{array}$ \\
\hline $\begin{array}{l}\text { Jenis Adsorben (Type of adsorbent) } \\
\text { - Bentonit } \\
\text { - Arang Aktif (Activated charcoal) }\end{array}$ & $\begin{array}{l}175,167 \\
172,428\end{array}$ & ${ }^{A}$ & $\begin{array}{l}170,598 \\
167,792\end{array}$ & ${ }_{\mathrm{B}}^{\mathrm{A}}$ \\
\hline $\begin{array}{l}\text { Adsorben (Adsorbent) } \\
-4 \% \\
-3 \% \\
-2 \%\end{array}$ & $\begin{array}{l}177,250 \\
174,208 \\
169,935\end{array}$ & $\begin{array}{l}\text { A } \\
\text { B } \\
\text { C }\end{array}$ & $\begin{array}{l}172,613 \\
169,615 \\
165,358\end{array}$ & $\begin{array}{l}\text { A } \\
\mathrm{B} \\
\mathrm{C}\end{array}$ \\
\hline $\begin{array}{l}\text { Kombinasi (Combination) } \\
\text { - Bentonit 4\% } \\
\text { - Bentonit 3\% } \\
\text { - Arang Aktif (Activated charcoal) 4\% } \\
\text { - Arang Aktif (Activated charcoal) 3\% } \\
\text { - Arang Aktif (Activated charcoal) 2\% } \\
\text { - Bentonit 2\% }\end{array}$ & $\begin{array}{l}178,640 \\
176,940 \\
175,860 \\
171,475 \\
169,950 \\
169,920\end{array}$ & $\begin{array}{l}\text { A } \\
\text { AB } \\
\text { B } \\
\text { C } \\
\text { C } \\
\text { C }\end{array}$ & $\begin{array}{l}174,640 \\
172,290 \\
171,065 \\
166,940 \\
165,370 \\
165,345\end{array}$ & $\begin{array}{l}\text { A } \\
\text { AB } \\
\text { B } \\
\text { C } \\
\mathrm{C} \\
\mathrm{C}\end{array}$ \\
\hline
\end{tabular}

Keterangan (Remark) : 1) Huruf yang sama tidak berbeda nyata (The same letter are not significantly different)

Pemberian arang aktif sebesar $2 \%$ dapat digunakan dalam pemurnian minyak kemiri karena telah mampu memperbaiki sifat minyaknya. Selanjutnya perlu juga dilakukan suatu penelitian untuk mengetahui penggunaan persentase arang aktif yang lebih rendah dari $2 \%$ dalam pemurnian minyak kemiri.

\section{DAFTAR PUSTAKA}

AOCS. 1951. Official and Tentative Methods of the American Oil Chemist's Society 2nd Ed. American Oil Chemist's Society. Chicago.

Badan Standarisasi Nasional. 1998a. Standar Nasional Indonesia 01-1684-1998. Kemiri. Jakarta.

Kemiri. Jakarta.

1998b. Standar Nasional Indonesia 01-4462-1998. Minyak

Jacobs, M. B. 1958. The Chemistry Analisys of Food and Food Products. Roberto Krieger Publ Inc. New York.

Ketaren, S. 1986. Pengantar Teknologi Minyak dan Lemak. Universitas Indonesia Press. Jakarta. 
Plofesi, Y. 1997. Pengaruh Perendaman dan Perebusan Sebelum Pengupasan Terhadap Rendemen dan Sifat Fisiko-Kimia Minyak Kemiri. IPB. Bogor.

Sudarmadji, S., B. Haryono dan Suhardi. 1989. Analisa Bahan Makanan dan Pertanian. Penerbit Liberty Yogyakarta. Yogyakarta.

Ward, J. A. 1982. Pre-pressing of oil from rapeseed and sunflower dalam Plofesi. Skripsi, tidak dipublukasikan.

Yusnita. E., B. Wiyono dan D. Setyawan. 1999. Pengaruh suhu dan waktu pemasakan biji kemiri terhadap sifat minyaknya. Buletin Penelitian Hasil Hutan 17 (2) :101 - 112. 